\title{
Preliminary characterization, androgen-dependence and ontogeny of an abundant protein from mouse vas deferens
}

\author{
C. Taragnat, M. Berger and Cl. Jean \\ Physiologie Comparée et Endocrinologie, CNRS U.A. 360, Université Biaise-Pascal, Les Cezeaux, \\ B.P. 45, 63170 Aubière, France
}

\begin{abstract}
Summary. Polyacrylamide gel electrophoresis analysis revealed that the vas deferens of adult mouse contains a major protein. Mouse vas deferens protein is a basic glycoprotein with a molecular weight of $34800 \pm 300$. The protein represents $17 \pm 0.7 \%$ and $42 \pm 2.4 \%$ of soluble proteins from homogenate and luminal fluid respectively, an estimate based on densitometric scanning of polyacrylamide gels. The protein originated from the vas deferens since it was not detected in blood plasma or in sexual organs and it was still present after ligation of the epididymis.

Changes in androgen status of the animal markedly affected the vas deferens protein. After castration a progressive decrease in the protein was observed and its relative percentage dropped to $2 \pm 0.4 \%$ after 45 days. The concentration of the protein returned to precastration levels after 2 weeks of testosterone treatment but oestradiol, progesterone and corticosterone were ineffective in this respect. The vas deferens protein was not synthesized in significant amounts until animals were 20 days old and its concentration increased rapidly from 20 to 30 days in concert with the pubertal increase of androgens in the vas deferens.
\end{abstract}

Keywords: vas deferens; major protein; androgens; mouse

\section{Introduction}

The vas deferens is known to have an ultrastructure well suited for the production and secretion of proteins. Its epithelial cells, in the proximal region, contain an abundance of rough endoplasmic reticulum and an extensive array of Golgi complexes (Flickinger, 1973; Hamilton, 1975). There is also some evidence that a large number of enzymes and other substances are present in the secretions of vas deferens of various mammalian species (Setty et al., 1974). However, knowledge of the extent to which the vas deferens is dependent on androgens for its normal function is limited. Like the other male accessory sexual organs its functional and structural integrity depends on the presence of circulating androgens (Chinoy \& Chinoy, 1983) and it can be considered as a site for control of fertility under androgenic regulation (Chinoy, 1985). However, the nature and mechanism by which the substances responsible for sperm storage and survival act in the vas deferens are still unknown. Numerous studies in rodents (FournierDelpech et al., 1973; Cameo \& Blaquier, 1976; Brooks \& Higgins, 1980) and primates (Haider et al., 1983; Tezon et al., 1985) indicate that the epididymis synthesizes and secretes specific androgendependent proteins, some of which coat the sperm surface. Only limited data are available about specific proteins secreted from the vas deferens (Wenstrom \& Hamilton, 1984; Taragnat et al., 1986). While exploring the possibility of the presence of androgen-dependent proteins in the vas deferens, we have observed a band of protein of $M_{\mathrm{r}} 34500$ which is reduced by castration (Taragnat et al., 1986). Studies were therefore undertaken to examine this protein. 


\section{Materials and Methods}

Animals. Mice of the Swiss strain (CD-1, Charles River France) were raised in the laboratory under standardized conditions. To investigate the role of androgens, adult males were castrated under light ether anaesthesia and different steroids were administered for 2 weeks to males castrated 45 days previously. Testosterone, oestradiol$17 \beta$, progesterone and corticosterone were dissolved in sesame oil and injected (s.c.) twice daily ( $75 \mu \mathrm{g} /$ injection). Controls received vehicle only. The animals were killed by decapitation $1 \mathrm{~h}$ after the last injection. Excised tissues, carefully freed from surrounding connective tissue and fat, were placed in $600 \mu l$ ice-cold Buffer A $(0.25 \mathrm{M}$ sucrose; $3 \mathrm{mM}-\mathrm{MgCl}_{2} ; 25 \mathrm{~mm}$-Tris; $0.5 \mathrm{~mm}$-phenylmethylsulphonyl fluoride, $\mathrm{pH} 7.5$ ) and stored at $-80^{\circ} \mathrm{C}$ until assayed.

Collection of proteins from the vas deferens. The vas deferens was removed between its emergence from the tail of epididymis and its junction with the excretory duct of the seminal vesicle. It was divided into two equal segments called proximal (epididymal) and distal (caudal) parts. To prevent epididymal fluid from entering the vas, after light ether anaesthesia each epididymis was ligated ( 4 weeks) at the point where the intra-epididymal coiled tubule becomes straight. The materials used in all experiments were proteins from luminal fluid or from homogenized tissue. Luminal contents were collected from the distal end of the vas deferens by injection of Buffer A into the vas. After centrifugation at $15000 \mathrm{~g}$ for $10 \mathrm{~min}$ to sediment spermatozoa, the supernatant was retained and used as luminal fluid. Otherwise, vasa deferentia were homogenized for $30 \mathrm{sec}$ at $4^{\circ} \mathrm{C}$ in $600 \mu \mathrm{l}$ Buffer $\mathrm{A}$ in a glass-glass hand homogenizer (Braun, Melsungen, F.R.G.). After centrifugation at $15000 \mathrm{~g}$ for $10 \mathrm{~min}$ the supernatant fluid was then retained and used as homogenate.

Polyacrylamide gel electrophoresis. Electrophoresis was performed under denaturing conditions (Laemmli, 1970). Electrophoresis was carried out on slab gels $(120 \times 140 \times 1.5 \mathrm{~mm})$ using a Model 220 dual vertical slab gel cell from Bio-Rad Laboratories (Richmond, CA). SDS protein samples $(60 \mu \mathrm{g})$ were applied at $12.5 \%$ resolving gels with a $4.5 \%$ stacking gel and run at $20 \mathrm{~mA}$ at room temperature until the tracking dye (bromophenol blue) reached the bottom of the gel. Gels were then stained with $0.25 \%$ Coomassie Brilliant Blue in an aqueous solution containing $50 \%(\mathrm{v} / \mathrm{v})$ methanol and $10 \%(\mathrm{v} / \mathrm{v})$ acetic acid for $45 \mathrm{~min}$ at room temperature and destained in the same solution without dye. Two-dimensional electrophoresis was done using non-equilibrium $\mathrm{pH}$ gradient gel electrophoresis (NEPHGE) in the first dimension (O'Farrell et al., 1977). Lyophilized aliquants containing $200 \mu \mathrm{g}$ proteins were dissolved directly in lysis buffer containing $9.5 \mathrm{M}$-urea, $2 \%$ Nonidet P-40,5\% $\beta$-mercaptoethanol and $2 \%$ ampholines (pH 3-10). Sample overlay solution was made of $9 \mathrm{M}$-urea and $1 \%$ ampholines; $0.01 \mathrm{M}$-orthophosphoric acid $\left(\mathrm{H}_{3} \mathrm{PO}_{4}\right)$ was used as anode solution while the cathode solution was $0.02 \mathrm{M}-\mathrm{NaOH}$. NEPHGE was carried out at $200 \mathrm{~V}$ for the first $15 \mathrm{~min}, 300 \mathrm{~V}$ for the next $30 \mathrm{~min}, 400 \mathrm{~V}$ for $15 \mathrm{~h}$ and $800 \mathrm{~V}$ for $\mathrm{l} \mathrm{h}$ in $0.3 \times 13.5 \mathrm{~cm}$ tubes. After the electrophoretic runs the gels were frozen. When ready to use, they were placed in equilibrium buffer containing $10 \%$ glycerol, $2.3 \%$ SDS, $5 \% \quad \beta$-mercaptoethanol and $0.12 \mathrm{M}$-Tris pH 6.8 for $30 \mathrm{~min}$. The gels were then placed on top of the stacking gel and covered with a solution containing $1 \%$ agarose in equilibrium buffer. The second dimension was run according to the method of Laemmli (1970) using $0.75 \mathrm{~mm}$ thick slab gels.

Lectin affinity procedure. After electrophoresis proteins were transferred to nitrocellulose sheets (Towbin et al., 1979) and they were visualized by lectin affinity procedures. To prevent the non-specific binding of the reagents to the nitrocellulose, nitrocellulose sheets were incubated for $2 \mathrm{~h}$ at $37^{\circ} \mathrm{C}$ in a saturation buffer (TBS): $10 \mathrm{~mm}$-Tris pH 6.8; $0.15 \mathrm{M}-\mathrm{NaCl}$; BSA $3 \%$. The lectins from Canavalia ensiformis (Con A), Asparagus pea (Asp. p) and wheat germ (WGA) were biotin labelled. All nitrocellulose strips were incubated in the lectin solution at room temperature for $1 \mathrm{~h}$. After washing (three times, $5 \mathrm{~min}$ per wash) the strips were incubated at room temperature for $1 \mathrm{~h}$ in peroxidaselabelled avidin $(2.5 \mu \mathrm{g} / \mathrm{ml})$. The peroxidase was revealed by soaking in a fresh solution of $0.3 \mathrm{mg} 4$ chloro-1-naphthol/ $\mathrm{ml}$ in ethanol and $0.05 \% \mathrm{H}_{2} \mathrm{O}_{2}$ (in buffer, $10 \mathrm{~mm}$-Tris $\mathrm{pH} 7.4 ; 0.15 \mathrm{M}-\mathrm{NaCl}$ ). The reaction was interrupted after $30 \mathrm{~min}$ by washing with water.

Densitometric scanning. Gels were scanned using an LKB ultroscan XL laser densitometer. The relative areas of the individual peaks were calculated by the following relationship: $\%$ relative peak area $=$ (individual peak area/total peak area) $\times 100$.

Protein and DNA assays. Protein were determined by the procedure of Lowry et al. (1951) using bovine serum albumin as standard. DNA was measured according to Burton (1956).

Radioimmunoassays. Testosterone and dihydrotestosterone were measured as described by Jean-Faucher et al. (1984). The sensitivity of the method was $45 \pm 10 \mathrm{pg}$ for testosterone and $55 \pm 12 \mathrm{pg}$ for DHT. The intraand interassay coefficients of variation were respectively 6 and $6.1 \%$ for testosterone, and 9 and $8.6 \%$ for DHT.

Statistics. Values are means \pm s.e.m. The significance of differences between means was calculated using Student's $t$ test. Differences were considered to be significant when $P<0.05$. 


\section{Results}

Origin of the vas deferens protein

SDS polyacrylamide gel electrophoresis of a whole vas deferens homogenate of adult mouse demonstrates the presence of a major protein band with an apparent molecular weight of 35000 when its mobility is compared to protein standards (Fig. 1). The other two prominent bands had the same mobility as albumin $\left(M_{\mathrm{r}} 67000\right)$ and ovalbumin $\left(M_{\mathrm{r}} 43000\right)$. Densitometric scanning indicated that the relative area of the vas deferens protein accounted for $17 \pm 0.7$ and $42 \pm 2.4 \%$ of the total area of soluble proteins found in homogenate and luminal fluid respectively $(n=5)$. Homogenates from the proximal and distal vas contained similar amounts of protein (19 \pm 0.6 and $22 \pm 0 \cdot 4 \%$ respectively) $(n=5)$.

Ligation of the cauda epididymidis ( 4 weeks) had no effect on the amount of vas deferens protein (Fig. 2). This protein is a characteristic feature of the vas deferens since it could not be detected in blood plasma or in homogenates from testis, epididymis, prostate and seminal vesicles (Fig. 2).

\section{Preliminary characterization of the protein}

Determination of apparent molecular weight, calculated by comparison with molecular weight markers (Pharmacia Fine Chemicals, Uppsala, Sweden) run on the same slabs, yielded a value of $34800 \pm 300(n=6)$.

Using NEPHGE in the first dimension, the mouse vas deferens protein seems to be composed of two closely separated spots (Fig. 3) with isoelectric points about 8 (calculated by comparison with pHi calibration kits: Pharmacia Fine Chemicals). The staining of polyacrylamide gels with periodic acid-Schiff reagent after electrophoresis of proteins from vas deferens homogenate showed that the protein is a glycoprotein (data not given). The detection of carbohydrate components with lectins showed that the vas deferens protein was only recognized by Asp. p., indicating the presence of fucose in the protein. The binding specificity was controlled by incubating nitrocellulose sheets with the lectin Asp. p. and its specific sugar (fucose) Fig. 4).

\section{Effect of castration}

The vas deferens of the adult mouse undergoes a significant involution in the absence of androgenic stimulation (Table 1). Figure 5 depicts the time course of the response of the vas deferens protein after orchidectomy. The protein disappeared progressively and was much reduced by 45 days after castration.

\section{Effect of testosterone treatment}

After 2 weeks of testosterone administration, weight and protein content of the vas deferens increased but were only partly restored because of the absence of spermatozoa. The negative effect of castration on the vas deferens protein could be completely reversed by the administration of testosterone, as shown by polyacrylamide gel electrophoresis (Fig. 5) and densitometric scanning (Table 1).

\section{Steroid specificity induction}

The ability of testosterone to reverse the effects of castration was not shared by oestradiol and progesterone which had only a small effect (Fig. 5). Corticosterone, the principal mouse glucocorticoid, was ineffective. 


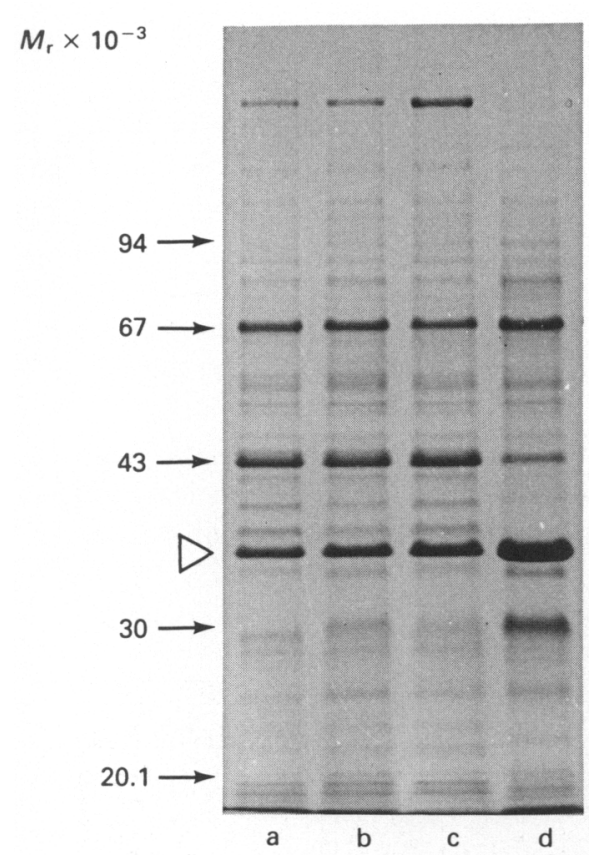

Fig. 1

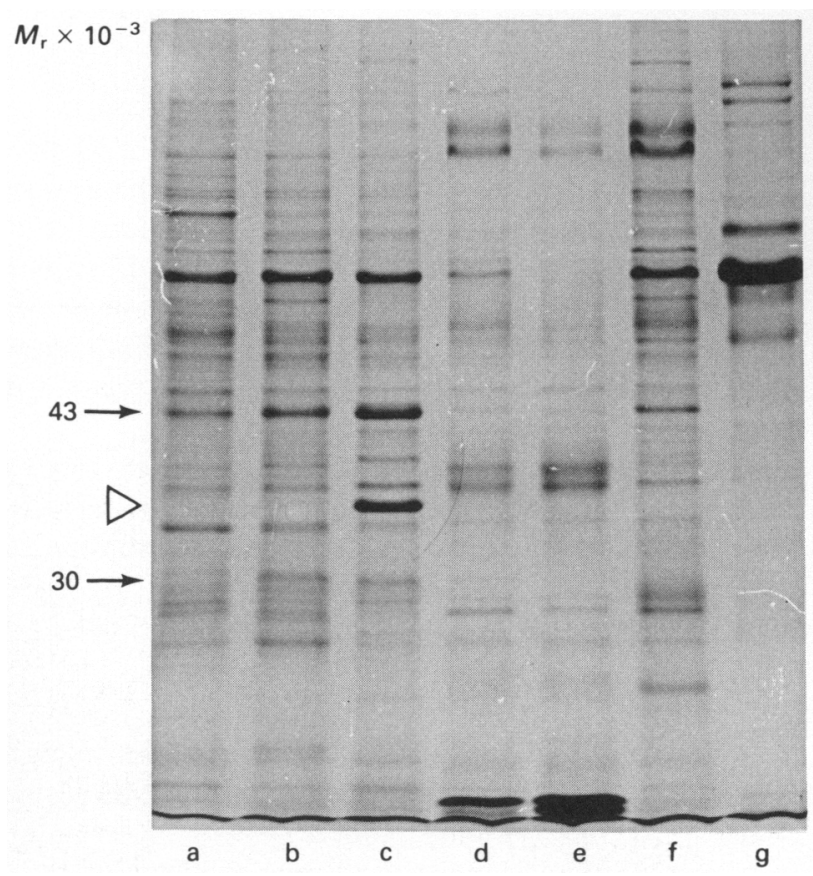

Fig. 2

Fig. 1. Polyacrylamide gel electrophoretic analysis of proteins from adult mouse vas deferens: (a) homogenate from whole vas deferens; (b) homogenate from proximal vas deferens; (c) homogenate from distal vas deferens; (d) luminal fluid. Each lane was loaded with $60 \mu \mathrm{g}$ proteins. Proteins were stained with Coomassie Blue. The white arrow indicates position of the vas deferens protein. The positions and molecular weights of standard proteins run in a parallel lane are also shown.

Fig. 2. Polyacrylamide gel electrophoretic analysis of proteins from homogenates of (a) testis, (b) epididymis, (c) vas deferens from mice in which a ligature was placed between the cauda epididymis and the vas for 4 weeks, (d) seminal vesicles plus coagulating glands, (e) seminal vesicles, (f) prostate and (g) blood plasma. The vas deferens protein (white arrow) is only present in the vas deferens. Each lane was loaded with $60 \mu \mathrm{g}$ proteins. Proteins were stained with Coomassie Blue.

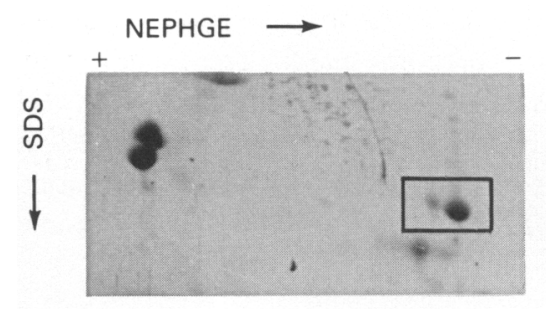

(a)



(b)

Fig. 3. Results of NEPHGE gel electrophoresis. (a) Close-up region of two-dimensional gel with proteins $(200 \mu \mathrm{g})$ from adult mouse vas deferens. The rectangle indicates the region including the vas deferens protein. (b) Higher magnification of the boxed area in (a) showing that the protein seems to be composed of two closely separated spots marked with arrows. Proteins were stained with Coomassie Blue. 


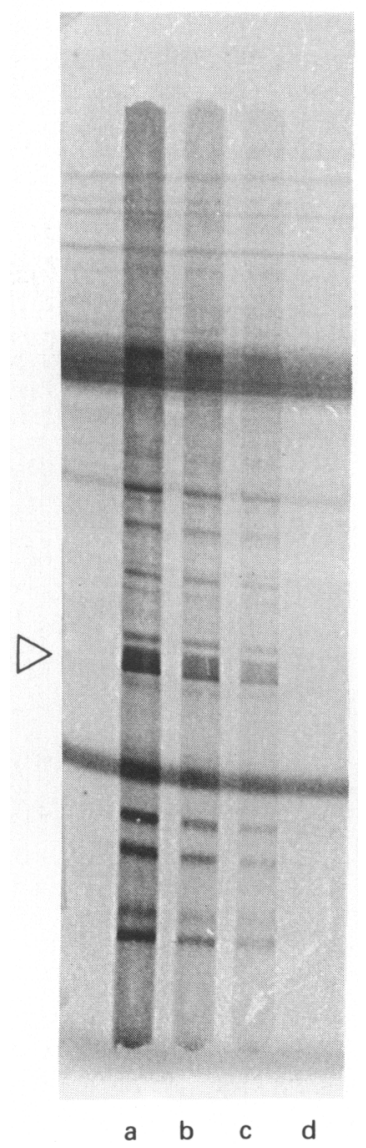

Fig. 4



Fig. 5

Fig. 4. Demonstration of lectin (Asparagus pea) binding by homogenate from whole vas deferens. Each lane was loaded with $20 \mu \mathrm{g}$ proteins, run by electrophoresis, transferred and revealed as described in 'Materials and Methods': (a) $5 \mu \mathrm{g}$ Asparagus pea $/ \mathrm{ml}$; (b) $2.5 \mu \mathrm{g} / \mathrm{ml}$; (c) $1 \mu \mathrm{g} / \mathrm{ml}$; and (d) as in (b) but with the presence of fucose $(16 \mu \mathrm{g} / \mu \mathrm{l})$ in the incubation medium. The white arrow indicates the position of the vas deferens protein as revealed by staining of the nitrocellulose sheet by Ponceau Red.

Fig. 5. Effect of castration and of steroid replacement on the vas deferens protein. Polyacrylamide gel electrophoretic analysis showed that the protein present in control (a) disappears progressively in adult castrated males killed 3 (b), 10 (c), 30 (d) and 45 (e) days after the operation. When testosterone (f), oestradiol-17 $\beta$ (g), corticosterone (h) and progesterone (i) were injected for 2 weeks ( $75 \mu \mathrm{g}$ twice daily) to males castrated 45 days previously, the protein was induced only by testosterone treatment. Each lane was loaded with $60 \mu \mathrm{g}$ proteins. Proteins were stained with Coomassie Blue. White arrow indicates the position of the vas deferens protein.

\section{Influence of age on weight and biochemical characteristics of mouse vas deferens}

Animals were studied between 10 and 60 days of age (fertility occurred around Day 40 ). The weight of the vas deferens increased rapidly from 10 to 60 days and this increase was parelleled by similar changes in DNA and protein content (Table 2). The testosterone and DHT contents increased rapidly after 20 days of age, particularly testosterone content. The vas deferens protein 
Table 1. Effect of androgen withdrawal or replacement on the weight and biochemical values of the mouse vas deferens

\begin{tabular}{lcccc}
\hline Treatment & $\begin{array}{c}\text { Weight } \\
(\mathrm{mg})\end{array}$ & $\begin{array}{c}\text { DNA } \\
(\mu \mathrm{g})\end{array}$ & $\begin{array}{c}\text { Protein } \\
(\mu \mathrm{g})\end{array}$ & $\begin{array}{c}\text { Vas deferens } \\
\text { protein }(\%) \S\end{array}$ \\
\hline $\begin{array}{l}\text { Controls* } \\
\text { Castrated } \dagger\end{array}$ & $32 \pm 1^{\mathrm{a}}$ & $96 \pm 4^{\mathrm{a}}$ & $1540 \pm 44^{\mathrm{a}}$ & $17 \pm 0 \cdot 7^{\mathrm{a}}$ \\
$\begin{array}{l}\text { Castrated } \\
\text { testosterone } \ddagger\end{array}$ & $15 \pm 1^{\mathrm{b}}$ & $55 \pm 5^{\mathrm{b}}$ & $541 \pm 40^{\mathrm{b}}$ & $2 \pm 0.4^{\mathrm{b}}$ \\
\hline
\end{tabular}

Values are means \pm s.e.m. for 10 mice.

*Intact, 90-day-old mice.

tCastrated at 2 months of age and killed 45 days later.

¥Castrated at 2 months and treated with testosterone heptylate for 2 weeks.

\$Estimated from densitometric scanning of Coomassie Blue stained gels (means of 5 scans \pm s.e.m.)

Values with different superscript letters are significantly different $(P<0.001)$.

Table 2. Influence of age on the weight and biochemical values of the mouse vas deferens

\begin{tabular}{lcccccc}
\hline $\begin{array}{l}\text { Age } \\
(\text { days })\end{array}$ & $\begin{array}{c}\text { Weight } \\
(\mathrm{mg})\end{array}$ & $\begin{array}{c}\text { DNA } \\
(\mu \mathrm{g})\end{array}$ & $\begin{array}{c}\text { Protein } \\
(\mu \mathrm{g})\end{array}$ & $\begin{array}{c}\text { Testosterone } \\
(\mathrm{pg})\end{array}$ & $\begin{array}{c}\text { DHT } \\
(\mathrm{pg})\end{array}$ & $\begin{array}{c}\text { Vas deferens } \\
\text { protein* } \\
(\%)\end{array}$ \\
\hline 10 & $2 \pm 0 \cdot 1$ & $10 \pm 1$ & $93 \pm 5$ & $4 \pm 1$ & $18 \pm 2$ & $1 \pm 0 \cdot 3$ \\
20 & $8 \pm 0 \cdot 3$ & $36 \pm 2$ & $427 \pm 27$ & $11 \pm 3$ & $30 \pm 6$ & $8 \pm 0.9$ \\
30 & $19 \pm 0 \cdot 5$ & $42 \pm 1$ & $850 \pm 52$ & $63 \pm 15$ & $69 \pm 20$ & $16 \pm 0.6$ \\
60 & $31 \pm 1$ & $90 \pm 5$ & $1450 \pm 60$ & $440 \pm 168$ & $117 \pm 26$ & $17 \pm 0.6$ \\
\hline
\end{tabular}

Values are means \pm s.e.m. for 10 mice.

*Estimated from densitometric scanning of Coomassie Blue stained gels (means of 5 scans\pm s.e.m.).

was not synthesized in significant amounts until animals were 20 days old (data not given) and its concentration rose abruptly between 20 and 30 days to reach adult levels (Table 2).

\section{Discussion}

The present study shows that the vas deferens of adult mice contains a very large amount of a protein which represents $17 \%$ and $42 \%$ of soluble proteins from homogenate and luminal fluid respectively, an estimate based on densitometric scanning of polyacrylamide gels. This protein is a specific secretion product of the vas deferens since it was present in luminal fluid and could not be detected by polyacrylamide gel electrophoresis in blood plasma or in testis, epididymis, prostate and seminal vesicles. Other specific proteins have been described in rat genital secretions: androgen binding protein secreted by testis (French \& Ritzen, 1973), prostatic binding protein by prostate (Heyns \& De Moor, 1977), specific epididymal proteins by epididymis (Fournier-Delpech et al., 1973; Cameo \& Blaquier, 1976; Brooks \& Higgins, 1980) and seminal vesicle secretory proteins by seminal vesicles (Higgins et al., 1976). The observations made for the mouse vas deferens resemble those in the rat prostate in which it has been estimated that up to $40 \%$ of total protein synthesis is directed towards a major secretory protein (Parker et al., 1982). Similarly, in the seminal vesicles, two secretory proteins account for $25 \%$ of the total protein synthesis (Higgins et al., 1976). The situation is different in the epididymis since in this organ the proportion of total protein synthesis 
devoted to the production of secretory proteins varied only from 4 to $15 \%$ (Brooks, 1981) and since there is no single protein forming a predominant species. Comparison between species of proteins secreted by epididymis, vas deferens, prostate and seminal vesicles of rodents is difficult because of the differences in the methods of study used. As judged by its electrophoretic mobility, molecular weight and pI values, the mouse vas deferens protein is different from major proteins secreted by rat prostate (Heyns \& De Moor, 1977) and rat seminal vesicles (Higgins et al., 1976). In the rat epididymis, proteins of $M_{\mathrm{r}} 30000-33000$ have been described (Fournier-Delpech et al., 1973; Cameo \& Blaquier, 1976; Brooks \& Higgins, 1980) but they were acidic proteins while the mouse protein is basic. Flickinger et al. (1986) have reported the presence, in the epididymal fluid of adult mice, of an unglycosylated protein of $M_{\mathrm{r}} 35000$ which represents $5 \%$ of the luminal soluble proteins. It is not known whether this mouse epididymal protein has some homology with the mouse vas deferens protein.

The present work showed that the amount of vas deferens protein depends on androgens. After castration the vas deferens protein almost completely disappeared but very slowly in agreement with the pattern described for other secretory proteins (Heyns et al., 1978). The effect of castration is abolished by administration of testosterone and these changes are specifically related to testosterone since oestradiol and progesterone were unable to increase the amounts of vas deferens protein to the same extent as testosterone. The effect of castration and testosterone treatment on the level of the protein may reflect changes in the mRNA levels as shown for prostatic binding protein (Page \& Parker, 1982), seminal vesicle secretory proteins (Fawell \& Higgins, 1984) and epididymal proteins (Brooks et al., 1986). The appearance of significant amounts of vas deferens protein in the immature (10-20 days old) mice occurred in the presence of very low concentrations of androgens in blood (Jean-Faucher et al., 1978) as well as in the vas deferens. It is possible that during this period there are synergistic effects between androgens and other factor(s) such as pituitary hormones. The rapid increase of vas deferens protein in the prepubertal mice is coincident with the rise of androgen concentrations in blood and vas deferens. In 30-day-old males the protein was a massive percentage of total proteins although the vas deferens was not yet at full development as judged by DNA, protein and androgen content. The presence of large amounts of vas deferens protein at this age precedes the entry of spermatozoa into the epididymis and vas deferens (35-40 days). Other androgen-dependent proteins (Heyns et al., 1978; Kistler et al., 1981; Cameo \& Blaquier, 1976) show similar marked changes as a function of age.

In conclusion, the mouse vas deferens contains and secretes a large amount of a protein of $M_{\mathrm{r}}$ 34800 which is regulated by androgens. Because of its abundant production this protein should be a useful probe for studies on androgen regulation of messenger RNA synthesis and translation during sexual maturation.

\section{References}

Brooks, D.E. (1981) Secretion of proteins and glycoproteins by the rat epididymis: regional differences, androgen-dependence and effects of protease inhibitors, procaine and tunicamycin. Biol. Reprod. 25, 1099-1117.

Brooks, D.E. \& Higgins, S.J. (1980) Characterization and androgen-dependence of proteins associated with luminal fluid and spermatozoa in the rat epididymis. J. Reprod. Fert. 59, 363-375.

Brooks, D.E., Means, A.R., Wright, E.J., Singh, S.P. \& Tiver, K.K. (1986) Molecular cloning of the cDNA for two major androgen-dependent secretory proteins of 18.5 Kilodaltons synthesized by the rat epididymis. J. biol. Chem. 261, 4956-4961.

Burton, K. (1956) A study of the conditions and mechanism of the diphenylamine reaction for the colorimetric esti- mation of desoxyribonucleic acid. Biochem. J. 62, 315-323.

Cameo, M.S. \& Blaquier, J.A. (1976) Androgen controlled specific proteins in rat epididymis. $J$. Endocr. 69, 47-55.

Chinoy, N.J. (1985) Structure and physiology of mammalian vas deferens in relation to fertility regulation. J. Biosci. 7, 215-221.

Chinoy, M.R. \& Chinoy, N.J. (1983) Differential androgen requirements of proximal and distal vas deferens of albino rats and possible potentiation of androgen action by ascorbic acid. Ind. J. exp. Biol. 21, 335-338.

Fawell, S.E. \& Higgins, S.J. (1984) Androgen regulation of specific mRNAs, endoplasmic reticulum and Golgi-system. Molec. cell. Endocr. 37, 15-27. 
Flickinger, C.H.J. (1973) Regional variations in endoplasmic reticulum in the vas deferens of normal and vasectomized rats. Anat. Rec. 176, 205-224.

Flickinger, C.H.J., Herr, J.C. \& Ertl, K.E. (1986) Identification and isolation of epididymal luminal proteins of the mouse. J. Androl. 7, 163-168.

Fournier-Delpech, S., Bayard, F. \& Boulard, C. (1973) Contribution à l'étude de la maturation du sperme. Etude d'une protéine acide de l'épididyme chez le rat. Dépendance androgène, relation avec l'acide sailique. C. r. hebd. Séanc. Soc. Biol. 147, 1989-1995.

French, F.S. \& Ritzen, E.M. (1973) A high affinity androgen-binding protein (ABP) in rat testis: evidence for secretion into efferent duct fluid and absorption by epididymis. Endocrinology 93, 88-95.

Haider, M.Z., Quazi, M.H., Khanum, A. \& Arslan, M. (1983) Effect of testosterone on epididymal proteins in castrated thesus monkeys. Am. J. Primat. 4, 73-80.

Hamilton, D.W. (1975) Structure and function of the epithelium lining the ductuli efferentes, ductus epididymis and ductus deferens of the rat. In Handbook of Physiology. Vol. V, section 7, pp. 259-301. Eds D. W. Hamilton \& R. O. Greep. Am. Physiological Society, Washington, D.C.

Heyns, W. \& De Moor, P. (1977) Prostatic binding protein: a steroid-binding protein secreted by rat prostate. Eur. J. Biochem. 78, 221-230.

Heyns, W., Van Damme, B. \& De Moor, P. (1978) Secretion of prostatic binding protein by rat ventral prostate: influence of age and androgen. Endocrinology 103, 1090-1096.

Higgins, S.J., Burchell, J.M. \& Mainwaring, W.I.P. (1976) Androgen-dependent synthesis of basic secretory proteins by the rat seminal vesicle. Biochem. J. 158, 271-282.

Jean-Faucher, Ch., Berger, M., De Turckheim, M., Veyssiere, G. \& Jean, Cl. (1978) Developmental patterns of plasma and testicular testosterone in mice from birth to adulthood. Acta endocr., Copenh. 89, $780-788$.

Jean-Faucher, Ch., Berger, M., De Turckheim, M., Veyssiere, G. \& Jean, Cl. (1984) Sexual maturation in male mice treated with cyproterone acetate from birth to puberty. J. Endocr. 102, 103-107.

Kistler, M.K., Ostrowski, M.C. \& Kistler, W.S. (1981) Developmental regulation of secretory protein synthesis in rat seminal vesicle. Proc. natn. Acad. Sci. U.S.A. 78, 737-741.

Laemmli, U.K. (1970) Cleavage of structural proteins during the assembly of the head of bacteriophage T4. Nature, Lond. 227, 680-685.

Lowry, O.H., Rosebrough, N.J., Farr, A.L. \& Randall, R.J. (1951) Protein measurement with the folin phenol reagent. J. biol. Chem. 193, 265-275.

O'Farrell, P.Z., Goodman, H.M. \& O'Farrell, P.H. (1977) High resolution two-dimensional electrophoresis of basic as well as acidic proteins. Cell 12, 1133-1142.

Page, M.J. \& Parker, M.G. (1982) Effect of androgen on the transcription of rat prostatic binding protein. Molec. cell. Endocr. 27, 343-355.

Parker, M., Needham, M. \& White, R. (1982) Prostatic steroid binding protein: gene duplication and steroid binding. Nature, Lond. 298, 92-94.

Setty, B.S., Chowdury, S.R. \& Jehan, Q. (1974) Biochemical composition of human vas deferens. Contraception 9, 601-607.

Taragnat, C., Berger, M. \& Jean, Cl. (1986) Identification and androgen-dependence of proteins in the mouse vas deferens. Int. J. Androl. 9, 299-311.

Tezon, J.G., Vazquez, M.H., Pineiro, L., De Larminat, M.A. \& Blaquier, J.A. (1985) Identification of androgen-induced proteins in human epididymis. Biol. Reprod. 32, 584-590.

Towbin, H., Staehelin, T. \& Gordon, J. (1979) Electrophoretic transfer of proteins from polyacrylamide gels to nitrocellulose sheets: procedure and some applications. Proc. natn. Acad. Sci. U.S.A. 76, 4350-4354.

Wenstrom, J.C. \& Hamilton, D.W. (1984) Synthesis and secretion of proteins in vitro by isolated epithelial strips from the proximal and distal vas deferens of the rat. Int. J. Androl. $7,215-235$.

Received 8 December 1987 